\title{
The Research Competence, Critical Thinking Skills and Digital Literacy of Indonesian EFL Students
}

\author{
Rohmani Nur Indah \\ English Literature Department, Universitas Islam Negeri Maulana Malik Ibrahim, Malang, Indonesia \\ Toyyibah \\ English Language Teaching Department, Institute Agama Islam Negeri Kediri, Indonesia \\ Ary Setya Budhiningrum \\ English Language Teaching Department, Institute Agama Islam Negeri Kediri, Indonesia
}

Nur Afifi

Linguistics Department, Macquarie University, Australia

\begin{abstract}
This project aims to investigate the relationship between English as Foreign Language (EFL) students' research skills, critical thinking skills, and engagement with technology or their digital literacy. EFL students' research competence is expected to support their academic performance on writing papers and assignments. It also demands the development of their critical thinking skills. Their engagement in technology involves the use of social media, online networks, and the use of several applications. This study takes the sample of EFL students from two institutions, namely UIN Malang and IAIN Kediri, Indonesia, to see whether there is a similar performance in both Islamic higher education institutions in terms of students' online research competence, critical thinking skills, and similar trend on the engagement with technology. The data collection method covers questionnaire and quiz. This result demonstrates a significant correlation between research competence and digital literacy. Concerning the insignificant relation between digital literacy and critical thinking, it proves that the digital literacy does not always automatically support the enhancement of critical thinking skills. Understanding the relationship between online research competence, critical thinking, and digital literacy is a crucial step in developing Indonesian EFL teaching syllabi and material supporting students' academic success in higher education context.
\end{abstract}

Index Terms - research competence, critical thinking, digital literacy, English as Foreign Language

\section{INTRODUCTION}

Today teaching EFL to students as digital netizens means letting them be exposed to the global online network and explore their e-skills. Students' engagement with information and communication technology involves the use of social media, online networking, and several applications. EFL students not only learn through face-to-face interaction, but also have a discussion online (Akarasriworn \& Ku, 2013). Some teachers also prefer to encourage engagement in classroom interaction virtually or through synchronous online education (Francescucci \& Foster, 2013). It results in flexibility and engagement of teaching and learning to support effective learning experience (Olt, 2018). Here, it appears that the development of the information age requires the students' ability to master technology. The question is, does the technology ability of Indonesian students support their academic skills? This research attempts to explore this inquiry.

Students need to acquire various research competence in the context of studying in the university, one of which is evaluative judgment skill required not only for the current learning but also for learning throughout life (Boud \& Soler, 2016). It encapsulates the interaction between individuals and further ends with performing reflective practice (Tai et al., 2018). In this case, performing the research competence on making an evaluative judgment is affected by peer interaction, such as peer review (Nicol, 2014) and their engagement with resources from the internet (Indah \& Kusuma, 2016).

In the era of rapid information, EFL students are required to access large amounts of information available on the internet. In doing so, they need to effectively employ their digital literacy, including evaluating information, synthesizing, and collaborating with others through online facilities (Frisch et al., 2018). By developing these skills through digital tools, at the same time, students can develop their inquiry learning as one of the ways to improve critical thinking and self-efficacy (Frisch et al., 2013). Students' engagement to resources mediates the enhancement of their critical thinking (Indah, 2017). In the context of Islamic higher education in Indonesia, questions still arise, whether the 
ease of access to technology provided has supported the academic development of the students, or has not been fully utilized optimally.

In higher education, the fashion now is research-oriented teaching. This term generally refers to all of those teaching approaches by providing students with the opportunity to develop their research competence (Böttcher \& Thiel, 2018). Islamic higher education aims to support the enhancement of students' research competence which includes their critical thinking, giving them opportunities to develop the skills that belong to the demand to cope with the dynamic of current information and communication technology. However, the preliminary study showed that not all Islamic higher education in Indonesia optimally facilitate the students through the courses or means to enhance their research competence, critical thinking and digital literacy.

This study explores students' research competence and their digital literacy at two institutions of Islamic higher education in Indonesia. It begins with the assumption that students' engagement with technology by using their critical thinking skills to some extent becomes the basis for developing their research competence. In other words, the stronger engagement to gadget or other information technology devices will directly contribute to the better skill to optimize the research tools provided online for EFL students and their critical thinking skills. Understanding the relationship between online research competence, critical thinking skills, and technology engagement is an important step in developing EFL teaching syllabi and material supporting students' academic success.

The purpose of this study is to obtain a description of the relationship patterns between EFL students' research competence, critical thinking skills, and their engagement with technology. The other goal is to get an ideal model of the relationship between students' research competence, critical thinking skills, and their engagement with technology. As for the findings regarding the ideal model of relations between students' research competence, critical thinking skills, and their engagement with technology, theoretically it can make a scientific contribution in understanding the application of critical thinking theory (Paul \& Elder, 2019).

\section{LITERATURE REVIEW}

Some studies that have relevant findings regarding the topic proposed in this study are categorized into four trends based on the focus, namely research competence, critical thinking, digital literacy, and other factors. Regarding the focus on research competence, new instrument is developed to assess university students' research competence (Böttcher \& Thiel, 2018) in several contexts such as health professionals (O'Keeffe et al., 2019) and education (Leach et al., 2016). The student's research skill is also, to some extent, affected by the contribution of librarian (Kelly, 2019), and technology-based instructional model (Valyukevych et al., 2021).

In developing critical thinking skills through online learning materials, there are a number of relevant strategies. These strategies involve the importance of navigation, metacognitive summary strategies, attitudes toward ICT, and social online reading strategies (Lim \& Jung, 2019). Metacognitive skill development, as one of the critical thinking skills, can be developed through online tools (Visser \& Flynn, 2018).

In light of the digital literacy of students, studies show that students have obstacles in using computers (Chan et al., 2016), lack of deep knowledge of the technologies (Bullen et al., 2008), and have less in-depth application knowledge or problem-solving skills (Kvavik, 2005). In this case, it does not mean that the earlier the students use ICT, the better digital competence they have as there is no significant relationship between the age of using ICT in childhood and the perceived digital competence (Juhanak et al., 2019). Besides, the use of educational technologies in personalized learning does not affect a student's self-accessed digital skills (Schmid \& Petko, 2019), although it may influence the student's process of language acquisition (Alivi \& Mardiana, 2020). It supports the fact that students shared similar digital cyber-culture in the context of pedagogy (Ayale-Perez \& Joo-Nagata, 2019).

In addition to these findings, there is a research suggesting that several factors may influence students' use of ICT such as socioeconomic status, cultural/ethnic background, gender, and discipline specialization (Kennedy et al., 2008). In addition, the nature and frequency of students' internet use differ based on age and socioeconomic status (Livingstone $\&$ Bober, 2004). The age is a factor in ICT use, but it was not the most important consideration; the gender gap and gaps between socioeconomic groups in terms of ICT use may be closing (Nasah et al., 2010).

From the previous studies, it is obvious that current finding on student's research competence is related to direct support such as research education and learning materials. This study argues that the research competence is initiated by the development of critical thinking skills and supported by ICT and the student's digital literacy. The relation between students' critical thinking and their digital literacy is supporting current finding on the context of online education (Visser \& Flynn, 2018). In addition, the use of ICT among students who are considered digital native is still worth examining as the shared cyber-culture among net-geners today does not always mean similar digital literacy. Accordingly, this study highlights the relationship between the diversity of students' critical thinking skills and digital literacy to shape their research competence in the context of Islamic higher education in Indonesia.

\section{METHOD}

This study investigates whether in Islamic higher education institutions the students share similar performance in terms of students' research competence and similar trend on the engagement with technology. It involves an Islamic 
State University (UIN) and an Islamic State College (IAIN) in Indonesia. These institutions were chosen because the preliminary study showed that students in both institutions have a high interest in research and technology utilization. Empirical data is still needed about the correlation between research skills and critical thinking with research capabilities

The population of this study is EFL students in Indonesia. The accessible population is the EFL students from two institutions namely English Department of UIN Malang and English Tadris (Language Teaching) of IAIN Kediri. As the sample, the participants are 195 students in the third year of their study assuming that they have taken the course on research methodology.

As data collection tools, this study involved the use of a questionnaire. The questionnaire comprises three parts: the first concerns the characteristics of the students, the second seeks to assess the students' research competence, and the third seeks to investigate the students' e-skills or their engagement with technology. The questionnaires are distributed extensively through online as well as offline contact.

There are five aspects elaborated to assess the students' research competence (Böttcher \& Thiel, 2018). They are as follows: 1) skills in reviewing the state of research, 2) methodological skills, 3) skills in reflecting on research findings, 4) communication skills, and 5) content knowledge. The students' e-skills were assessed through four dimensions: 1) the generic use of a computer, 2) the generic use of the Internet, 3) the use of IT for pedagogic purposes, and 4) the use of IT for collaborative work purposes. This instrument rated both the students' research competence and their e-skills on a 5-point response scale, ranging from " 1 - strongly disagree" to " 5 - strongly agree."

On the assessment of critical thinking skills, the students were faced with two tasks, namely identifying fact or generalization, and distinguishing between objective report and subjective report. The first task consists of five items. The instruction is to prefer factual statement or generalization, for instance, "all the guests at the party preferred the chocolate cake". The second task consists of two items in the form of a short passage in which the students were asked to decide whether it belongs to objective or subjective report.

Before distributed, the questionnaire was validated by experts. The experts evaluated the phrasing and had the opportunity to propose an alternative phrasing for inappropriate items. Afterwards, a try out to detect any potential problems and misunderstandings on the questionnaire was carried out. Any problems from the try out then were addressed before the data collection procedure. The data collected excludes respondents that declare inconsistent responses and respondents who did not answer all the questions. As the final stage, this study also employed Focus Group Discussion (FGD). It involved senior lecturers, head of English department, curriculum experts and syllabus developer to evaluate the model of proportional items of courses supporting the development of the three skills observed in this study.

The analysis in this study was carried out to assess the student's research competence, critical thinking and digital literacy. The next analysis tested the hypothesis that the stronger the engagement to gadget or other information technology devices, the better the research competence the students have. In addition, it also examines whether the higher critical thinking skills, the better the research competence the students' have. Following the research approach, the correlation statistics employed to do hypothesis testing was Pearson bivariate correlation.

\section{FINDINGS}

The EFL students as the participant in this study had shown that to some extent they have been involved to research skills. From table 1, it can be inferred that the variable of research competence is similar to the median, while in critical thinking and digital literacy the mean is lower than the median. It implies that although they are still in the process of projecting themselves to the final stage of their research competence namely thesis writing, the students had practiced their ability in doing a systematic inquiry. In addition, the significant correlation occurs in the relation between research competence and digital literacy as shown in table 2 .

TABLE 1

THE SCORES OF RESEARCH COMPETENCE, CRITICAL THINKING, AND DigitAl LiTERACY

\begin{tabular}{|l|l|l|l|}
\hline Measures & Research Competence & Critical Thinking & Digital Literacy \\
\hline Mean & 27.5 & 4.6 & 32.70 \\
\hline Std. Error of Mean & .29 & .11 & .35 \\
\hline Median & 27.00 & 5.00 & 33.00 \\
\hline Mode & 25.00 & 4.00 & 36.00 \\
\hline Std. Deviation & 4.12 & 1.49 & 4.97 \\
\hline Variance & 16.96 & 2.23 & 24.74 \\
\hline Skewness & -.371 & -.313 & -.22 \\
\hline Range & 26.00 & 6.00 & 28.00 \\
\hline Minimum & 11.00 & 1.00 & 17.00 \\
\hline Maximum & 37.00 & 7.00 & 45.00 \\
\hline
\end{tabular}


TABLE 2

THE RELATIONSHIP BETWEEN RESEARCH COMPETENCE, CRITICAL THINKING, AND DiGITAL LITERACY

\begin{tabular}{|c|c|c|c|c|}
\hline & & $\begin{array}{l}\text { Digital } \\
\text { Literacy }(\mathrm{X})\end{array}$ & $\begin{array}{l}\text { Critical } \\
\text { Thinking (Y) }\end{array}$ & $\begin{array}{l}\text { Research } \\
\text { Competence }(\mathrm{Z})\end{array}$ \\
\hline \multirow{3}{*}{$\begin{array}{l}\text { Digital } \\
\text { Literacy }(\mathrm{X})\end{array}$} & Pearson correlation & 1 & .011 & $.566(* *)$ \\
\hline & Sig. (2-tailed) & & .879 & .000 \\
\hline & $\mathrm{N}$ & 195 & 195 & 195 \\
\hline \multirow{3}{*}{$\begin{array}{l}\text { Critical } \\
\text { Thinking (Y) }\end{array}$} & Pearson correlation & .011 & 1 & -.003 \\
\hline & Sig. (2-tailed) & .879 & & .972 \\
\hline & $\mathrm{N}$ & 195 & 195 & 195 \\
\hline \multirow{3}{*}{$\begin{array}{l}\text { Research } \\
\text { Competence } \\
(\mathrm{Z})\end{array}$} & Pearson correlation & $.566(* *)$ & -.003 & 1 \\
\hline & Sig. (2-tailed) & .000 & .972 & \\
\hline & $\mathrm{N}$ & 195 & 195 & 195 \\
\hline
\end{tabular}

\section{DISCUSSION}

\section{A. The Level of Research Competence, Critical Thinking and Digital Literacy}

This study measures the research competence from what the EFL students practice during their academic study period. The criteria mentioned in the finding such as using internet for finding research resources, deciding data, identifying gaps and so forth belong to scientific literacy (Chang et al., 2011). In this case, the student's level of research skill is also influenced by some other disposition, one of which is self-evaluation. Students who can self-evaluate their own problem-solving skills can improve their competence, including research competence (Yildirim et al., 2019).

However, not all students spontaneously connect their knowledge to research methods or other scientific thinking elements in their education to everyday academic practice. These elements also present in the occupational context (Wernersson \& Orwehag, 2016). Further, they describe the freedom and independence they have in their choice of research question and form of work as appealing and encouraging.

Critical thinking covers EFL students' ability to use thoughts clearly and rationally about what is done or believed. This ability actively involves intellectual processes and skills to do the following: conceptualizing, applying, analyzing, synthesizing, evaluating information obtained through observation, experience, reflection, reasoning and scientific communication. In this study, these domains are represented in the ability to identify the factual statements or generalization, and to distinguish between subjective or objective statements. The EFL students responding to the assessment of critical thinking skills had shown that they have been operating their higher-order thinking skills to some extent. The higher percentage shows it in responding all of the items correctly especially in identifying report which is assumed to be easier than to distinguish between generalization or factual statement. For the students of both institutions, the biggest challenge is in identifying factual statement. The findings also show that the level of the student's critical thinking is still fair.

Developing critical thinking for the research participants is not easy since they may face barriers, such as poor metacognitive skills, a fixed mindset, and bias of the fact that thinking is effortful (Persky et al., 2019). Another aspect intervening in the representation of critical thinking skill is how the students use outside knowledge, intensive justification and critical assessment. In the finding, the assessment can show the weak spot in the student's critical thinking disposition (Beckmann \& Weber, 2015). To implement changes in the teaching of critical skills, it needs a critical thinking diagnosis approach integrated in the syllabus (Lu, 2013).

Understanding critical thinking means recognizing the skills that are being developed as a continuous process. As the skills are very complex, this study's finding shows that it needs more exposure through explicit teaching of critical thinking (Howard et al., 2015). Although to some extent it not enough and not always effective (Azizi-Fini et al., 2015), the finding of this study shows that the moderate level of critical thinking needs improvement. It can be done in the form of incorporating the skills with the content courses (Aizikovitsh-Udi \& Cheng, 2015).

Digital literacy means having the skills needed to live, learn, and work as an EFL student. Communication and access to information are increasing through digital technologies like internet platforms, social media, and mobile devices. In the findings of this study, the EFL students' responses to the assessment on digital literacy shown that they had varied pattern on the use of digital technology in their academic activities. Based on the student's statements, they strongly agree to their being easy to download music, movies, and images from the internet as the easiest digital activity in their daily lives. The sequence of the digital literacy dominantly occurring in the student's academic activities is as the following: (1) easy to download music, movies, and images from the internet; (2) manage online conversation or chat applications; (3) use the internet to communicate with instructors/classmates; (4) use word processing software easily; (5) able to arrange meeting new people online; (6) review online evaluations before purchasing online; (7) proficient at conducting group work using the internet; (8) proficient in presentation software; and (9) able to contribute to the web blogs.

The findings also show similar responses of the students in online shopping where they can review a product online before purchasing and meeting new people online. Whereas, various responses deal with the tendency in contributing to web blogs, downloading from internet, using chat applications, conducting online group work, communicating online 
with classmates and instructors, using presentation software, and proficient in word processing software. Overall, the findings show that the average level of the students' digital literacy is still fair. These students tend to use instrumental e-skill, that is the skill in the area of the operational manipulation of technology and strategic e-skill, covering the skill to look for relevant information to use pro-actively. The structural e-skill or the skill in structuring information becomes the second priority of the EFL students (Steyaert, 2002). However, the information e-skills involve the subskills of formal and substantial information skills (van Dijk, 2010). In this case, the students observed in this study employ the formal information skill in handling the computer networks such as file structures, menu structures, and hyperlinks when operating word processing software. They also use substantial information skills, namely the ability to find, select, process, and evaluate information in specific sources according to specific questions and needs.

In the findings, there is a different tendency in the use of information technology. UIN students utilize more on information technology for collaborative work purposes compared to IAIN students. However, both institutions' students show similar tendency in the use of computer, internet and the use of information technology for pedagogic purposes. These usages deal with the principal component of the modes of information technology (Youssef et al., 2015). However, these tendencies are related to digital competences encompassing the knowledge, abilities, skills, and attitudes needed for working in the digital age. The students needed such competences for nearly every knowledge occupation (Murawski \& Bick, 2017)

Based on the research data, it is obvious that UIN students use more the discussion forum of the online course compared to IAIN students. It shows how the EFL students engage with the chance to have academic discussion through online devices. Having online discussion also need to involve outside knowledge, intensive justification and critical assessment of any posts made by their peers. This activity should be guided by the content courses to improve students' critical thinking (Beckmann \& Weber, 2016).

The fact shown in this study that the students possess digital literacy skills and they use these digital literacy skills daily for academic performance purposes which is not only found in EFL students in Islamic Higher Education but it also occurs in other countries. The students of a university in Nigeria develop digital literacy skills despite the major challenges of electricity failure, low internet bandwidth, ICT facilities, and lack of digital development literacy program and standard (Ukwoma et al., 2016).

The digital literacy requires sufficient knowledge on information technology. The fact that not all of the EFL students observed in this study have adequate IT knowledge and skills is similar to that of Malaysian dental undergraduate students (Chan et al., 2016). The survey found that most of the students had access to computers or internet and possessed adequate IT knowledge and skills. However, there were still some students who complained about obstacles in using the computers and lacked of deep knowledge of the technologies themselves (Bullen et al. 2008).

The different tendency of digital literacy is related to several aspects including the awareness of improving both digital and life skills. The digital literacy brings framework into a powerful lever for digital inclusion (Nedungadi et al., 2018). This idea is urgent in Indonesia particularly in the era of online education or distant learning program during the pandemic period in the current year. This type of framework needs more work regarding how to instill the EFL students' motivation, interest and confidence in their engagement with digital learning process.

The distinction in terms of digital literacy in both institutions is supported by the different digital facilities and available access. In this case, access, skills and literacy-development are necessary for meaningful use of information technology. However, another concept is needed, namely socio-technical awareness (Hosman \& Comisso, 2020). This awareness influences the application and measurement of meaningful use of information technology for EFL students. Therefore, it is suggested that socio-technical awareness is introduced to empower students to make meaningful use of digital technologies (Hosman \& Comisso, 2020).

In the context of EFL students' digital literacy, the development needs more monitoring through the university policy. In this context, the information literacy mainly comprises technical skill and information management skill. Besides, digital literacy is composed of technical skill, cognitive skill and emotional-social skills (Tuamsuk \& Subramaniam, 2017). By enhancing digital literacy through the EFL content courses, at the same time, it augments the digital intelligence quotient of the students. Eight dimensions were developed to measure the digital intelligence quotient. They include aspects of digital identity, digital use, digital safety, digital security, digital emotional intelligence, digital communication, digital literacy and digital rights (N-Nan et al., 2019).

The data analysis performed a significant correlation in the relation between research competence and digital literacy as shown in table 2. This fact is supporting the finding on the students of nursing that student's research skill is also, to some extent, affected by the contribution of their literacy including digital literacy (Kelly, 2019). Table 2 demonstrates an insignificant contribution of critical thinking as this variable is integral to digital literacy and research competence. It is inseparable from enhancing the skills through online learning materials, and attitudes toward information technology (Lim and Jung, 2019). It is also improved through social online reading strategies and extensive reading (Zin and Eng, 2014).

Concerning the insignificant relation between digital literacy and critical thinking as shown in the finding of this study, survey of undergraduate students had similar results (Kvavik, 2005). The digital literacy does not always automatically support the enhancement of critical thinking skills. In this case, it also does not mean that the earlier the 
students use ICT, the better digital competence they have as there is no significant relationship between the age of using ICT in childhood and the perceived digital competence (Juhanak et al., 2019).

In the context of digital literacy for EFL students, Song (2008) shows that online collaborative educational websites in second or foreign languages allow EFL university students to improve their writing abilities. Fostering writing is also an effective for improving critical thinking skill (Asraf et al., 2018). This augment is undoubtedly affected by the digital literacy education, introducing ICT based curriculum and the association between library management in maintaining a regular training program on digital literacy. The library technological involvement significantly improves student technology-based learning skills (Rafi et al., 2019).

Regarding the need to enhance student's digital literacy, studies show that it needs more involvement of educators to present powerful instructional practices that link critical and digital literacies providing students with the skills to enlarge multiple viewpoints and promoting critical thinking skills (Amgott, 2018). Educators and students in technology learning environments also can make a good contribution towards offering pragmatic solutions (Al-Qallaf \& Al-Mutairi, 2016).

\section{B. The Model of Research Competence, Critical Thinking and Digital Literacy}

Based on the result of FGD in this study, curriculum developer, lecturer consortium and pedagogical practitioners agree that the courses should be designed in such a way to support the relation between research competence and digital literacy. So far each course supports the skill with the specific focus. Later on, with the demand of the current distant learning and online education process, it needs integral development of research competence and digital literacy. This issue becomes more significant related to integrating the technology during the pandemic era (Prasojo et al., 2020). This finding supports the results of previous studies that showed how research activities develop students' content knowledge and research, although they can perceive several problems during the process. Accordingly, research skills should be encouraged through several courses in any study programs (Elmas \& Aydin, 2017).

The students' research competencies have been formed since students take research courses, such as Research on Linguistics, Advanced Prose, and other courses that hone critical thinking. Even though during the lecture the students did not seem to actively participate in class discussions, in fact the results of the project papers were very good at representing their critical thinking skills. In the finding, it is clear that the students' research competence is basically supported by several courses that involve the dynamic of critical thinking. In both institutions, some similarities occur in the variation of the courses given in similar level and similar portion of digital literacy courses.

Research courses --such as quantitative and qualitative research methods, literary theories, literary criticism etc.-- are sufficient to provide exposure to various aspects of research. There is also non-credit course such as proposal seminars that can assist students sharpening the quality of their research proposals. In fact, if the proposal in the seminar is synchronized and is followed up as a thesis, the quality of the research will be even better. Hence, it takes lecturer commitment to prioritize assignments in research subjects that can finalize research competencies, especially maturity in a frame of mind. However, based on the FGD result, the student's research competence in average does not show significant improvement currently. Only some of the students can find new topic to develop for their research, while others still follow the topics that are considered saturated.

In the Indonesian context, the development of critical thinking skills is effective through certain strategies, for instance is the use of science inquiry model combined with a mind map in learning (Fuad et al., 2017) and learning about effective questioning (Defianty \& Wilson, 2019). Another research also shows that the best practice of teaching critical thinking skills for high school students is initiated by developing instructional design to promote higher-order thinking skills (Apino \& Retnawati, 2017). It is also considered effective by giving socio-scientific issues (Pratiwi et al., 2016) and using the discovery model (Suardana et al., 2018). Empowering student's critical thinking skills needs the improvement of student's reading interest (Mahanal et al., 2016), and also implementing project-based learning (Hakim et al., 2016) or problem-based learning (Khoiriyah et al., 2015). In addition, the implementation of project-based learning and group investigation can encourage the EFL students to think critically through planning, arguing, stating questions and problems, and analyzing and providing solutions to the surrounding environmental issues (Asyari et al., 2016). These strategies belong to the recommendation for an ideal model of instructional strategies in EFL context.

The result of FGD also concerns with supporting the student's research competence through online research skills that can be given in the form of regular training. In addition, these skills can be given integrated in some research subjects, as material enrichment. If there is a proposal seminar course as a special class, online research skills can be included there. It seems that it is simple and can be learned independently by students, but when it is not currently an obligation, online research skills are not properly honed.

\section{CONCLUSION AND RECOMMENDATION}

Regarding research competence, Indonesian EFL learners in this study show typical competence in using internet resources for the student's research projects and being able to decide which data or sources or materials to address the research questions. However, there is more indecision shown in some other criteria such as the ability to identify research gaps, to decide research method, to interpret research findings, to reflect research implications and to 
understand research publication standard. These aspects show the need of more exposure so that the improvement in these aspects can be done as the student's research competence is still fair.

In terms of critical thinking level, the EFL students responding to the assessment of critical thinking skills had shown that they have been operating their higher-order thinking skills to some extent. The higher percentage shows it in responding all of the items correctly especially in identifying report which is assumed to be easier than to distinguish between generalization or factual statement. For the students of both institutions, the biggest challenge is in identifying factual statement. The finding also shows that the level of the student's critical thinking is still fair.

The finding shows that the average level of the student's digital literacy is still fair. The students tend to use instrumental e-skill, that is the skill in the area of the operational manipulation of technology and strategic e-skill, covering the skill to look for relevant information to use pro-actively. In this case, the students observed in this study employ the formal information skill in handling the computer networks such as file structures, menu structures, and hyperlinks when operating word processing software. They also use substantial information skills, namely the ability to find, select, process, and evaluate information in specific sources according to specific questions and needs.

This study results in the significant correlation between research competence and digital literacy. Concerning the insignificant relation between digital literacy and critical thinking, it proves that the digital literacy does not always automatically support the enhancement of critical thinking skills. The different tendency of digital literacy is related to several aspects including the awareness of improving both digital and life skills.

Considering that the Indonesian EFL students' research competence level, critical thinking level and digital literacy level in both Islamic institutions are still fair, the finding of this study can be an evaluation of the curriculum. Therefore, as the study's implication, it needs revealing opportunities to instruct students in more effectively articulating transferable research skills. In addition, the finding of this study shows that the moderate level of critical thinking needs improvement. It can be done in the form of incorporating the skills with the content courses as suggested.

The different tendency of digital literacy is related to several aspects including the awareness of improving both digital and life skills. This type of framework needs more work regarding how to instill the EFL student's motivation, interest and confidence in their engagement with digital learning process. To improve the EFL student's digital literacy, the online research skill should be an integral part of learning programs at all courses.

\section{REFERENCES}

[1] Aizikovitsh-Udi, E., \& Cheng, D. (2015). Developing critical thinking skills from dispositions to abilities: Mathematics education from early childhood to high school. Creative Education, 6(04), 455-462.

[2] Akarasriworn, C., and Ku, H-Y. (2013). Graduate students' knowledge construction and attitudes toward online synchronous video conferencing collaborative learning environments. Quarterly Review of Distance Education, 14, 35-48.

[3] Alivi, J. S., \& Mardiana, W. (2020). Interrelation of technology and ideology in informal second language acquisition: A transdisciplinary framework. Paradigm, 3(1), 11-24.

[4] Allison, B., Hilton, A., O'Sullivan, T., Owen, A., \& Rothwell, A. (2016). Research skills for students. Routledge.

[5] Al-Qallaf, C. L., \& Al-Mutairi, A. S. (2016). Digital literacy and digital content supports learning. The Electronic Library, 34 (3), 522-547.

[6] Amgott, N. (2018). Critical literacy in \#DigitalActivism: Collaborative choice and action. The International Journal of Information and Learning Technology, 35 (5), 329-341.

[7] Apino, E., \& Retnawati, H. (2017). Developing instructional design to improve mathematical higher-order thinking skills of students. Journal of Physics: Conference Series, 812(1), 012100. IOP Publishing.

[8] Asraf, R. M., Ahmed, S., \& Eng, T. K. (2018). Using focused freewriting to stimulate ideas and foster critical thinking during prewriting. TESOL International Journal, 13(4), 67-81.

[9] Asyari, M., Al Muhdhar, M. H. I., \& Susilo, H. (2016). Improving critical thinking skills through the integration of problem based learning and group investigation. International Journal for Lesson and Learning Studies 46(4), 628-734.

[10] Ayale-Pérez, T., and Joo-Nagata, J. (2019). The digital culture of students of pedagogy specializing in the humanities in Santiago de Chile. Computers and Education, 133, 1-12.

[11] Azizi-Fini, I., Hajibagheri, A., \& Adib-Hajbaghery, M. (2015). Critical thinking skills in nursing students: A comparison between freshmen and senior students. Nursing and midwifery studies, 4(1), e25721.

[12] Beckmann, J., \& Weber, P. (2015). Cognitive presence in virtual collaborative learning: Assessing and improving critical thinking in online discussion forums. International Association for Development of the Information Society, 13(1), 51-58.

[13] Beckmann, J., \& Weber, P. (2016). Cognitive presence in virtual collaborative learning. Interactive Technology and Smart Education 13(1), 52-70.

[14] Bernhardt, P. E., \& Richmond, A. S. (2019). Promoting critical thinking through the use of student-generated case studies. In Handbook of Research on Critical Thinking Strategies in Pre-Service Learning Environments (pp. 438-447). IGI Global.

[15] Böttcher, F., and Thiel, F. (2018). Evaluating research-oriented teaching: A new instrument to assess university students' research competence. High Education, 75(1), 91-110.

[16] Bullen, M., Morgan, K., and Qayyum, A. (2008, October 20-22). The digital learner at BCIT and implications for an e-strategy. Research workshop of the European distance education network (EDEN), France.

[17] Chan, W. M., Chai, Y. Y., \& Abdullah, A. A. (2016). The use of information and communication technology among undergraduate students in dental training. Journal of Education and Ethics in Dentistry 6(1), 27-33.

[18] Chang, H. P., Chen, C. C., Guo, G. J., Cheng, Y. J., Lin, C. Y., \& Jen, T. H. (2011). The development of a competence scale for learning science: Inquiry and communication. International Journal of Science and Mathematics Education, 9(5), 1213-1233. 
[19] Cottrell, S. (2017). Critical thinking skills: Effective analysis, argument, and reflection. Macmillan International Higher Education.

[20] Defianty, M., \& Wilson, K. (2019). Fostering critical thinking through questioning in EFL. In Thinking Skills and Creativity in Second Language Education: Case Studies from International Perspectives (pp. 74-94). Routledge.

[21] Dwyer, C. P., \& Walsh, A. (2019). An exploratory quantitative case study of critical thinking development through adult distance learning. Educational Technology Research and Development, 68(1), 17-35.

[22] Elmas, E., \& Aydın, S. (2017). Pre-service foreign language teachers' perceptions of research skills: A qualitative study. The Qualitative Report 22(12), 3088-3101.

[23] Firdaus, F., Kailani, I., Bakar, M. N. B., \& Bakry, B. (2015). Developing critical thinking skills of students in mathematics learning. Journal of Education and Learning, 9(3), 226-236.

[24] Francescucci, A., \& Foster, M. (2013). The VIRI (virtual, interactive, real-time, instructor-led) classroom: The impact of blended synchronous online courses on student performance, engagement, and satisfaction. Canadian Journal of Higher Education, 43(3), 78-91.

[25] Frisch, J. K., Jackson, P. C., \& Murray, M. C. (2013). WikiED: Using web 2.0 tools to teach content and critical thinking. Journal of College Science Teaching, 43(1), 70-80

[26] Frisch, J. K.; Jackson, P. C., \& Murray, M. C (2018). Transforming undergraduate biology learning with inquiry-based instruction. Journal of Computing in Higher Education, 30, 211-236.

[27] Fuad, N. M., Zubaidah, S., Mahanal, S., \& Suarsini, E. (2017). Improving junior high schools' critical thinking skills based on test three different models of learning. International Journal of Instruction, 10(1), 101-116.

[28] Gholami, M., Moghadam, P. K., Mohammadipoor, F., Tarahi, M. J., Sak, M., Toulabi, T., \& Pour, A. H. H. (2016). Comparing the effects of problem-based learning and the traditional lecture method on critical thinking skills and metacognitive awareness in nursing students in a critical care nursing course. Nurse education today, 45(1), 16-21.

[29] Hakim, A., Liliasari, L., Kadarohman, A., \& Syah, Y. M. (2016). Improvement of student critical thinking skills with the natural product mini-project laboratory learning. Indonesian Journal of Chemistry, 16(3), 322-328.

[30] Hodges, T. S., Scott, C. E., Washburn, E. K., Matthews, S. D., \& Gould, C. (2019). Developing pre-service teachers' critical thinking and assessment skills with reflective writing. In Handbook of Research on Critical Thinking Strategies in Pre-Service Learning Environments (pp. 146-173). IGI Global.

[31] Hosman, L., \& Comisso, M. A. P. (2020). How do we understand "meaningful use" of the internet? Of divides, skills and socio-technical awareness. Journal of Information, Communication and Ethics in Society, 18(3), 461-479.

[32] Howard, L. W., Tang, T. L. P., \& Austin, M. J. (2015). Teaching critical thinking skills: Ability, motivation, intervention, and the Pygmalion effect. Journal of Business Ethics, 128(1), 133-147.

[33] Indah, R. N., \& Kusuma, A. W. (2016) Factors affecting the development of critical thinking of Indonesian learners of English language. Journal of Humanities and Social Science, 21(6), 86-94.

[34] Indah, R. N. (2017) Critical thinking, writing performance, and topic familiarity of Indonesian EFL learners. Journal of Language Teaching and Research, 8(2), 229-236.

[35] Juhaňák, L., Zounek, J., Záleská, K., Bárta, O., \& Vlčková, K. (2019). The relationship between the age at first computer use and students' perceived competence and autonomy in ICT usage: A mediation analysis. Computers and Education, 141(1), 103614.

[36] Kelly, S. L. (2019). Faculty perceptions of librarian value: The moderating relationship between librarian contact, course goals, and students' research skills. The Journal of Academic Librarianship, 45(3), 228-233.

[37] Kennedy, G., Krause, K.-L., Judd, T., Churchward, A., and Gray, K. (2008). First-year students' experiences with technology: Are they really digital natives? Australasian Journal of Educational Technology, 24(1), 108-122.

[38] Khoiriyah, U., Roberts, C., Jorm, C., \& Van der Vleuten, C. P. M. (2015). Enhancing students' learning in problem-based learning: validation of a self-assessment scale for active learning and critical thinking. BMC medical education, 15(1), 1-8.

[39] Kvavik, R. (2005). Convenience, communications, and control: How students use technology. In D. G. Oblinger and J. L. Oblinger (Eds.). Educating the net-generation (Chap. 7). Boulder, Co: Educause.

[40] Leach, M. J., Hofmeyer, A., \& Bobridge, A. (2016). The impact of research education on student nurse attitude, skill, and uptake of evidence-based practice: a descriptive longitudinal survey. Journal of Clinical Nursing, 25(1-2), 194-203.

[41] Lim, H. J., \& Jung, H. (2019). Factors related to digital reading achievement: A multi-level analysis using international large scale data. Computers and Education, 133(1), 82-93.

[42] Livingstone, S., \& Bober, M. (2004). Taking up online opportunities? Children's use of the Internet for education, communications, and participation. E-learning, 1(3), 395-419.

[43] Lu, P. Y. (2013). Critical thinking in a university EFL classroom: An intercultural syllabus. Asian EFL Journal, 71(1), 4-30.

[44] Mahanal, S., Zubaidah, S., Bahri, A., \& Maratusy, D. S. (2016). Empowering students' critical thinking skills through Remap NHT in biology classroom. In Asia-Pacific Forum on Science Learning and Teaching, 17(2), 1-13.

[45] McNamara, J., Sweetman, S., Connors, P., Lofgren, I., \& Greene, G. (2020). Using interactive nutrition modules to increase critical thinking skills in college courses. Journal of nutrition education and behavior, 52(4), 343-350.

[46] Murawski, M., \& Bick, M. (2017). Digital competences of the workforce - a research topic? Business Process Management Journal, 23(3), 721-734

[47] Na-Nan, K., Roopleam, T., \& Wongsuwan, N. (2019). Validation of a digital intelligence quotient questionnaire for employee of small and medium-sized Thai enterprises using exploratory and confirmatory factor analysis. Kybernetes, 49(5), $1465-1483$.

[48] Nasah, A., DaCosta, B., Kinsell, C., \& Seok, S. (2010). The digital literacy debate: an investigation of digital propensity and information and communication technology. Educational Technology Research \& Development, 58(1), 531-555.

[49] Nedungadi, P. P., Menon, R., Gutjahr, G., Erickson, L., \& Raman, R. (2018). Towards an inclusive digital literacy framework for digital India. Education + Training, 60 (6), 1-7. 
[50] Nicol, D. (2014). Guiding principles for peer review: unlocking learners' evaluative skills. In C. Kreber, C. Anderson, N. Entwistle, \& J. McArthur (Eds.), Advances and innovations in university assessment and feedback (pp. 197-224). Edinburgh University Press

[51] O'Keeffe, N., Cullinane, A. M., Greensmith, L., Bracken, S., O'Shaughnessy, N., Dennehy, C., \& Lambert, V. (2019). GP132 Developing research capacity: Baseline survey identifying research activity, skills, and supports for nurses in children's hospitals in Ireland. Archives of Disease in Childhood, 104(Suppl 3), A1-A428

[52] Olt, P. A. (2018). Virtually there: Distant freshmen blended in classes through synchronous online education. Innovative Higher Education, 43(5), 381-395.

[53] Paul, R., \& Elder, L. (2019). The miniature guide to critical thinking concepts \& tools. Rowman \& Littlefield.

[54] Persky, A. M., Medina, M. S., \& Castleberry, A. N. (2019). Developing critical thinking skills in pharmacy students. American journal of pharmaceutical education, 83(2), 7033-7042.

[55] Prasojo, L. D., Wijayanti, W., Yuliana, L., Agus, N., Habibi, A., \& Yaakob, M. F. M. (2020). Instruments' validation of access to motivation, skills, and use of digital technology: EFL context in Indonesia. Studies in English Language and Education, 7(2), 308-322.

[56] Pratiwi, Y. N., Rahayu, S., \& Fajaroh, F. (2016). Socio-scientific issues (SSI) in reaction rates topic and its effect on the critical thinking skills of high school students. Jurnal Pendidikan IPA Indonesia, 5(2), 164-170.

[57] Rafi, M., JianMing, Z., \& Ahmad, K. (2019). Technology integration for students' information and digital literacy education in academic libraries. Information Discovery and Delivery, 47(4), 203-217.

[58] Schmid, R., \& Petko, D. (2019). Does the use of educational technology in personalized learning environments correlate with self-reported digital skills and beliefs of secondary-school students? Computers and Education, 136(1), 75-86.

[59] Song, C. (2008), Educational games with blogs: Collaborating to motivate second language undergraduate critical thinking. Online Information Review, 32(5), 557-573.

[60] Steyaert, J. (2002) Inequality, and the digital divide: Myths and realities. In S. H. J. McNutt (Ed.), Advocacy, activism, and the internet (pp. 199-211). Lyceum Press.

[61] Suardana, I. N., Redhana, I. W., Sudiatmika, A. A., \& Selamat, I. N. (2018). Students' critical thinking skills in chemistry learning using local culture-based 7E learning cycle model. International Journal of Instruction, 11(2), 399-412.

[62] Tai, J; Ajjawi, R; Boud, D; Dawson, P., \& Panadero, E. (2018) Developing evaluative judgment: Enabling students to make decisions about the quality of work. Higher Education, 76(1), 467-481.

[63] Tuamsuk, K., \& Subramaniam, M. (2017). The current state and influential factors in the development of digital literacy in Thailand's higher education. Information and Learning Science, 118(5), 235-251.

[64] Ukwoma, S. C., Iwundu, N. E., \& Iwundu, I. E. (2016). Digital literacy skills possessed by students of UNN, implications for effective learning and performance. New Library World, 177(11), 702-720.

[65] Valter, K., \& Akerlind, G. (2010). Introducing students to ways of thinking and acting like a researcher: A case study of research-led education in the sciences. International Journal of Teaching and Learning in Higher Education, 22(1), 89-97.

[66] Valyukevych, T. V., Zinchenko, O.Z., Ishchenko, Y. O., Artemov, V., \& Nechaiuk, L. G. (2021) Research-oriented framework of training philology students' research skills based on corpus analytical software. European Journal of Educational Research 10(2), 671-680. https://doi.org/10.12973/eu-jer.10.2.671

[67] Van Deursen, A. J. A. M., \& van Dijk, J. A. (2010). Measuring internet skills. International Journal of Human-Computer Interaction, 26(10), 891-916.

[68] Visser, R., \& Flynn, A. B. (2018). What are students' learning and experiences in an online learning tool designed for cognitive and metacognitive skill development? Collected Essays on Learning and Teaching, 11(1), 129-140.

[69] Wernersson, I., \& Orwehag, M. H. (2016). Scholarly skills as everyday practice-implications for education. Higher Education, Skills and Work-Based Learning 6(3), 224-236.

[70] Willison, J., \& O'Regan, K. (2007). Commonly known, commonly not known, totally unknown: A framework for students becoming researchers. Higher Education Research and Development, 26(4), 393-409.

[71] Yildirim, J. G., Calt, A. C., \& Ardaha, M. (2019). Problem-solving skills of University nursing students and factors affecting them: A Cross-sectional study. Journal of Pakistan Medical Association, 69(2), 1717-1720.

[72] Youssef, A. B., Dahmani, M., \& Omrani, N. (2015). Information technologies, students' e-skills, and diversity of learning process. Educational Information Technology, 20(1), 141-159.

[73] Zin, Z. M., \& Eng, W. B. (2014). Relationship between critical thinking dispositions and critical reading skills of Malaysian ESL learners. The Asian EFL Journal Quarterly, 16(3), 41-68.

Rohmani Nur Indah is an associate professor teaching in the Department of English Letters at Universitas Islam Negeri Maulana Malik Ibrahim Malang, Indonesia. Her research interests are psycholinguistics, applied linguistics, and language teaching. She is currently the editor-in-chief of El Harakah journal of Islamic culture and local wisdom.

Toyyibah is the head of the Graduate Program of English Language Education of The State Islamic Institution (IAIN) Kediri, Indonesia. As an associate professor of English language teaching, her research interests include phonology, pragmatics, and madrasah education.

Ary Setya Budhi Ningrum is a senior lecturer at English Language Education Department of The State Islamic Institution (IAIN) Kediri. She is also an editor of the Journal of English Education and Linguistics Studies (JEELS). Her research interests are English language teaching, research methodology, and English for young learners. 
Nur Afifi, is a senior researcher of The State Islamic Institution (IAIN) Kediri currently pursuing her doctoral degree from Linguistics Department, Macquarie University, Australia. Her research interest includes English language teaching, rhetoric, and applied linguistics. 